\title{
The thermal structure at the topside and above of polar mesosphere summer echoes over Spitsbergen $78^{\circ} \mathrm{N}$
}

\author{
J. Lautenbach, J. Höffner, F.-J. Lübken, and M. Zecha \\ Leibniz-Institute of Atmospheric Physics, Schlossstraße 6, 18225 Kühlungsborn, Germany \\ Received: 12 January 2007 - Revised: 3 April 2007 - Accepted: 12 April 2007 - Published: 28 May 2008
}

\begin{abstract}
Simultaneous measurements of temperature and polar mesosphere summer echoes (PMSE) were performed at the polar cap $\left(78^{\circ} \mathrm{N}\right)$ during summer 2001 and 2003. In summer time the mesopause region is characterized by extremely low temperatures around $120 \mathrm{~K}$. It is remarkable that PMSE are practically never observed above $92 \mathrm{~km}$ although temperatures are low enough to allow the existence of ice particles. In this case study we compare the PMSE topside with temperatures measured by the potassium lidar and with frost point temperatures using water-vapor mixing ratios from models. We find striking discrepancies with our current understanding of ice particles and temperature in this region. In this case study we find that the temperature can be more than $20 \mathrm{~K}$ lower than the frost point temperature but no PMSE is observed above $92 \mathrm{~km}$ altitude. We show that the lack of PMSE does not necessarily imply that the temperature is too high.
\end{abstract}

Keywords. Atmospheric composition and structure (Aerosols and particles; Middle atmosphere - composition and chemistry) - Ionosphere (Ionospheric irregularities; Polar ionosphere)

\section{Introduction}

Remote sensing of layers in the upper mesosphere can provide important information about the thermal and dynamical background conditions in a part of our atmosphere which is experimentally difficult to access. One important example of such layers are so-called "polar mesosphere summer echoes" (PMSE). This phenomenon is related to ice particles which can only exist at these altitudes if the temperature is less then 120-150 K. Comparison of ice layers (e.g. PMSE) and temperature can be very helpful to get a detailed under-

Correspondence to: J. Lautenbach

(lautenbach@iap-kborn.de) stand of the relationship between the thermal structure of the mesopause region and the existence of these ice particles. This is important since the lack of PMSE is often automatically interpreted the temperature being too high or the water vapor concentration being to low; leading to further interpretations.

PMSE are very strong radar echoes at the radar half wavelength (i.e. Bragg scale) received from the summer mesopause region at polar latitudes. They were first observed in the late 1970s by radars in the VHF band (Czechowsky et al., 1979; Ecklund and Balsley, 1981). On the basis of some key ideas and observations published earlier an understanding of the physical processes leading to PMSE has been developed (e.g. Cho and Kelley, 1993; Cho and Röttger, 1997; Rapp and Lübken, 2004). In the polar summer mesopause region the temperature is low enough that ice particles can exist. These ice particles become charged due to the attachment of electrons in the background plasma of the D-region. The charged ice particles are transported by the turbulent velocity field leading to small scale structures in the spatial distribution of the charged particles and to small scale structures in the spatial distribution of the electron number density. Hence, the transport of charged ice particles by the turbulent velocity field leads to the occurrence of irregularities in the radio refractive index which is observed on the ground as PMSE by radar. So far the current PMSE theory is in agreement with the mean characteristics of PMSE and with in situ observations of plasma irregularities and turbulence (Rapp and Lübken, 2004). Most important, PMSE require the presence of ice particles and therefore supersaturation conditions, i.e.

$S=\frac{p_{\mathrm{H}_{2} \mathrm{O}}}{p_{\text {sat }}}>1$

where $S$ is the degree of saturation, $p_{\mathrm{H}_{2} \mathrm{O}}$ is the partial pressure of water-vapor $\left(X_{\mathrm{H}_{2} \mathrm{O}} \cdot p\right)$ and $p_{\text {sat }}$ is the saturation pressure of water-vapor over ice (Marti and Mauersberger, 1993).

Published by Copernicus Publications on behalf of the European Geosciences Union. 
Until now only few common volume temperature measurements have been performed by sounding rockets using the falling sphere technique to analyze the thermal structure of the PMSE at these high latitude (Lübken et al., 2004). These measurements are sporadic and represent only a snapshot of the atmospheric conditions. Furthermore, the falling sphere technique is restricted to altitudes below approximately $92 \mathrm{~km}$ which doesn't cover the region above PMSE (Lübken and Müllemann, 2003). At lower latitudes $\left(69^{\circ} \mathrm{N}\right)$ comparative measurements by radar, rockets and lidar were performed in the vicinity of PMSE, but again only sporadically or for short time periods (e.g. Lübken et al., 2002; Goldberg et al., 2004; She et al., 2006). These measurements show that PMSE generally occur during supersaturation. The non-PMSE cases did not exhibit any systematic or unexpected atmospheric conditions.

In this paper study we compare for the first time a continuous time series of co-located and simultaneously measured temperatures and PMSE at a very high latitude $\left(78^{\circ} \mathrm{N}\right)$. We show that a lack of PMSE does not automatically imply that the temperature is too high. After introducing the campaign and the instrumentation in Sect. 2 we compare the thermal structure inside and outside PMSE with the corresponding frost point temperature in Sect. 3. The geophysical implications of this observation are discussed in Sect. 4.

\section{Campaigns and instrumentation}

\subsection{Campaigns}

From May 2001 to October 2003 three field campaigns were conducted close to Longyearbyen $78^{\circ} \mathrm{N}, 15^{\circ} \mathrm{E}$ on the north polar island Spitsbergen which is part of the archipelago of Svalbard. The potassium lidar was installed at the beginning of May 2001 on a plateau $(450 \mathrm{~m})$ on the site of Svalsat (Svalbard Satellite Station). The combined 3 years of measurement cover the period from 28 February to 6 October. In 2001 (12 June-6 October) a total of $276 \mathrm{~h}$ of observations at 50 days were achieved (Höffner et al., 2006). A complete summary of the thermal structure obtained from the three campaigns will be published in the near future. At the end of October 2003 the potassium lidar was transported back to the Leibniz-Institute of Atmospheric Physics in Kühlungsborn (IAP). The SOUSY Svalbard Radar (SSR) was installed by the Max-Planck-Institut für Aeronomie in 1998 and is located in a distance of about $15 \mathrm{~km}$ to the potassium lidar. The atmospheric volumes observed in the mesophere by radar and lidar have a horizontal distance of $10 \mathrm{~km}$. Considering a typical horizontal extent of PMSE layers and structures this can be accounted as common volume (Lübken et al., 2004).

\subsection{Potassium Lidar}

The mobile potassium resonance lidar of the IAP is capable of measuring atmospheric temperatures and potassium in the mesopause region $(80-105 \mathrm{~km})$. With a narrowband alexandrite laser the $\mathrm{K}-\left(\mathrm{D}_{1}\right)$ resonance line at $769.9 \mathrm{~nm}$ is probed by scanning the laser wavelength by a few pm over the Doppler broadened absorption line. From the spectral shape of the effective backscatter coefficient vertical profiles of air temperature and potassium density are derived. Systematic temperature errors are estimated to $3 \mathrm{~K}$ not considering daylight capability. For a detailed description of the instrument see von Zahn and Höffner (1996). Since November 2000 the lidar has incorporated with a Faraday anomalous dispersion optical filter for daylight rejection which allows operation under polar summer conditions (Fricke-Begemann et al., 2002). The influence of the daylight filter on the temperature is less than $0.5 \mathrm{~K}$ (Höffner and Fricke-Begemann, 2005). The temperature data have a time resolution of $15 \mathrm{~min}$ and an altitude resolution of $200 \mathrm{~m}$.

\subsection{SOUSY Svalbard Radar}

The SSR is a VHF radar which is primarily used to study PMSE (Czechowsky et al., 1998). During these measurement it was operated at $53.5 \mathrm{MHz}$ with $70 \mathrm{~kW}$ peak power and a range (height) resolution of $300 \mathrm{~m}$. The vertical beam of the radar was used so as to obtain the highest possible altitude resolution. The original scientific aim and technical specification are summarized by Czechowsky et al. (1998) and Röttger et al. (2000). Results and capabilities for mesosphere observations were published by Rüster et al. (2001), comparative measurements with the EISCAT Svalbard Radar were published by Röttger (2001).

\section{Results}

In the following section we present the first case study of co-located and simultaneously measured temperatures and PMSE in the altitude range from $80 \mathrm{~km}$ up to $96 \mathrm{~km}$ at very high latitudes. Figure 1 shows temperature observations of approximately $5 \mathrm{~h}$ and the echo power from the SSR of $8 \mathrm{~h}$ on 6 July 2003. In order to achieve an equal resolution for both data sets we interpolated them to a grid of $5 \mathrm{~min}$ in time and $100 \mathrm{~m}$ in altitude. The temperature measurements which cover the altitude range from 89 to $92 \mathrm{~km}$ overlap the PMSE by up to $1 \mathrm{~km}$. We have divided the temperatures into 2 groups; those outside and inside (at the topside) of the PMSE. The red dots in Fig. 1 show the top side of PMSE which we define by the threshold of significantly detectable echo power above noise $(10 \mathrm{~dB})$. The red dots also indicate the region $(\Delta \mathrm{z} \pm 200 \mathrm{~m})$ where we define the measured temperatures as inside PMSE.

PMSE are constrained to an area of supersaturation because ice particle disappear quickly if it is too warm. The 


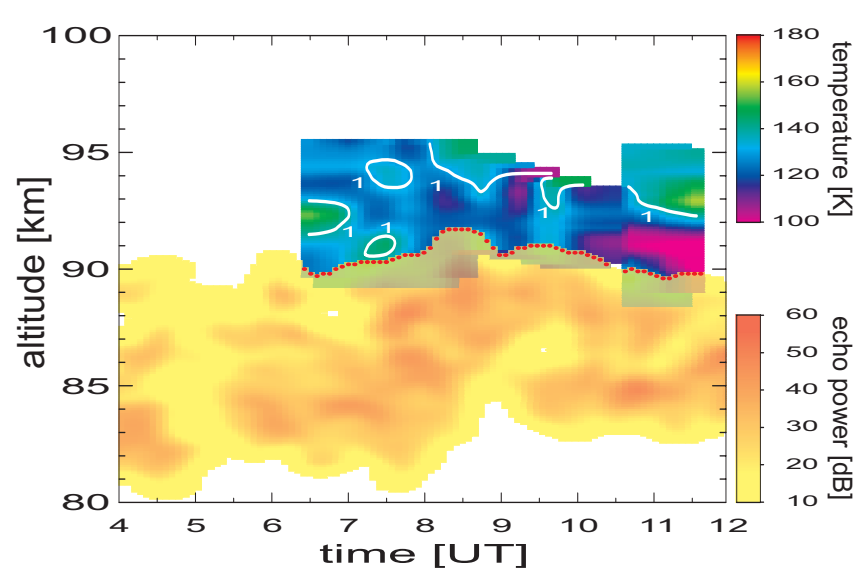

Fig. 1. Simultaneous measured temperature and PMSE over Spitzbergen on 6 July 2003. The frost point temperature (without freeze-drying-effect) is indicated by the white line by using the model of von Zahn and Berger (2003). The red dots show the top side of PMSE which is the region $(\Delta \mathrm{z} \pm 200 \mathrm{~m})$ where temperatures inside PMSE are taken.

degree of saturation is defined as $S=p_{\mathrm{H}_{2} \mathrm{O}} / p_{\text {sat }}$ (see Eq. 1). $p_{\text {sat }}$ varies exponentially with temperature, i.e., $S$ depends critically on temperature and to a lesser extent on watervapor mixing ratio. The degree of saturation $(S)$ is proportional to $p_{\mathrm{H}_{2} \mathrm{O}}$, hence at the same temperature and altitude (pressure) $S$ is proportional to the water-vapor mixing ratio. Unfortunately, no relevant measurements for the partial pressure of water-vapor are available. Therefore we use the modelled water-vapor mixing ratio of von Zahn and Berger (2003). They published two profiles for solstice where one is with freeze-drying-effect and the other without. In Fig. 2 frost point temperatures, $\mathrm{T}_{\mathrm{f}}$ (defined by $S=1$ ), are shown with and without freeze-drying-effect along with each measured temperature profile from 06:52-11:26. As can be seen the temperature variability is large, nevertheless most of the temperature profiles are below $\mathrm{T}_{\mathrm{f}}$. We will primarily use the non freeze-drying $\mathrm{H}_{2} \mathrm{O}$ values but we will also refer to the freezedrying case. The white line in Fig. 1 indicates $S=1$ without freeze-drying-effect. The region of $S>1$ shows that ice particles can exist up to $\sim 94 \mathrm{~km}$ altitude, but the PMSE is limited to altitudes below $\sim 92 \mathrm{~km}$.

In Fig. 3 we show the deviation between the actual measured temperatures $(\mathrm{T})$ and the frost point temperature without freeze-drying-effect. For comparison $T_{f}$ with freezedrying-effect is also shown. The green dots show the temperature measurements outside and the red dots inside the PMSE. As expected almost all temperatures inside PMSE are smaller than $T_{f}$. We note that with freeze-drying a much larger fraction of the PMSE is within a region of sublimation $\left(T>T_{f}\right)$. This indicates that freeze-drying may not always be important, which is in agreement with model calculations of ice particle generation, transport, and sublima-

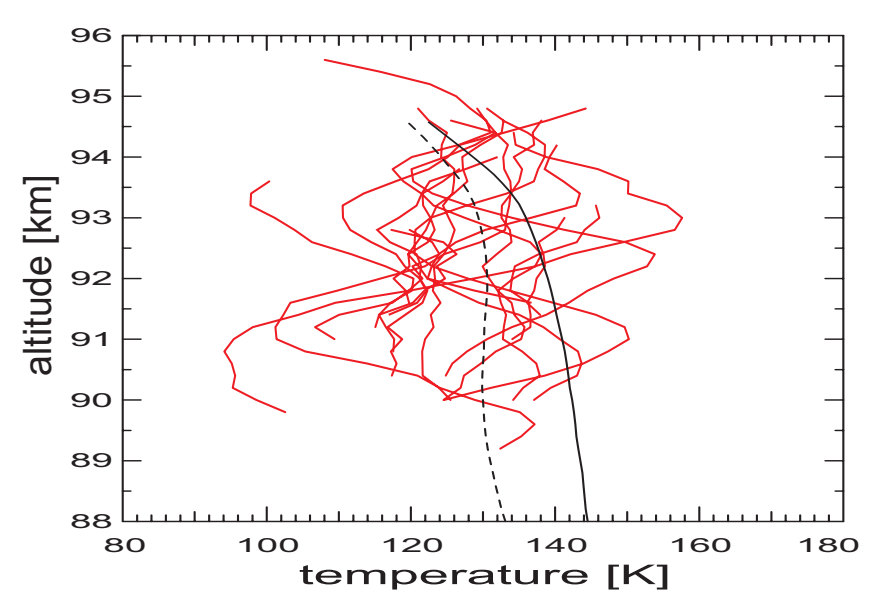

Fig. 2. Single temperature profiles every $15 \mathrm{~min}$ (red) from 06:42 to 11:26 UT measured by the potassium lidar on 6 July 2003. Dashed black profile correspond to $\mathrm{T}_{\mathrm{f}}$ with and black solid profile without freeze-drying-effect.

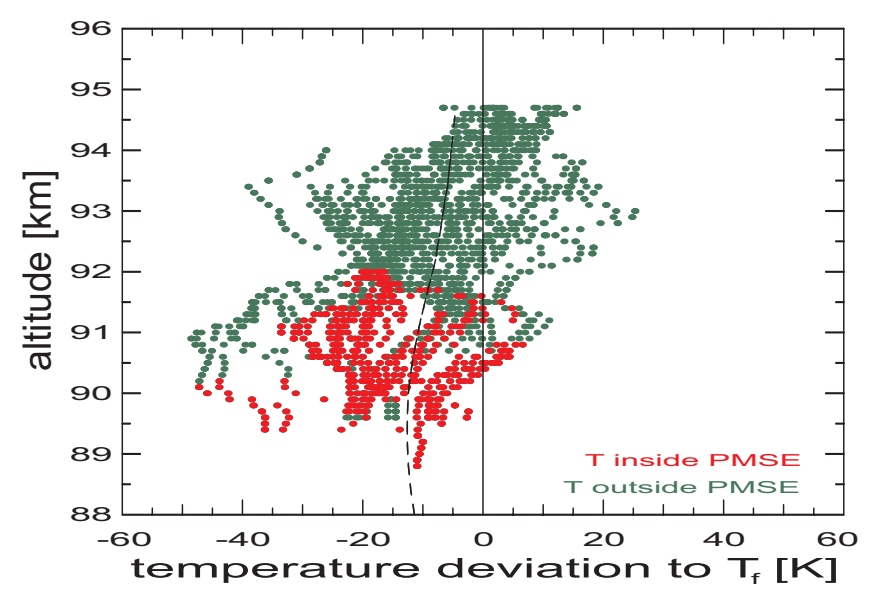

Fig. 3. Deviation of the actual measured temperature compared to $\mathrm{T}_{\mathrm{f}}$ without freeze-drying-effect on 6 July 2003. Green dots indicate the temperature outside and the red dots inside (at the topside $\Delta \mathrm{z} \pm 200 \mathrm{~m}$ ) of the PMSE. For comparison $\mathrm{T}_{\mathrm{f}}$ with freeze-dryingeffect is given as dashed line.

tion (Berger and Lübken, 2006). The temperatures outside the PMSE (green dots) are more than $20 \mathrm{~K}$ below $\mathrm{T}_{\mathrm{f}}$ up to altitudes of $94 \mathrm{~km}$. At this altitude and background temperature a deviation of $20 \mathrm{~K}\left(\mathrm{~T}-\mathrm{T}_{\mathrm{f}}\right)$ corresponds to $S \sim 10000$, i.e. the air is strongly supersaturated. Since $S$ is proportional to $p_{\mathrm{H}_{2} \mathrm{O}}$ this would require a reduction of $p_{\mathrm{H}_{2} \mathrm{O}}$ by a factor of 10000 compared to normal which is very unrealistic and contradicts model results of the strength of the freeze-dryingeffect (Berger and von Zahn, 2002).

Depending on the size of the condensation nuclei $(\mathrm{CN})$ and the background conditions water-vapor needs time to nucleate, i.e. to form an ice shell around the $\mathrm{CN}$. The exact time 


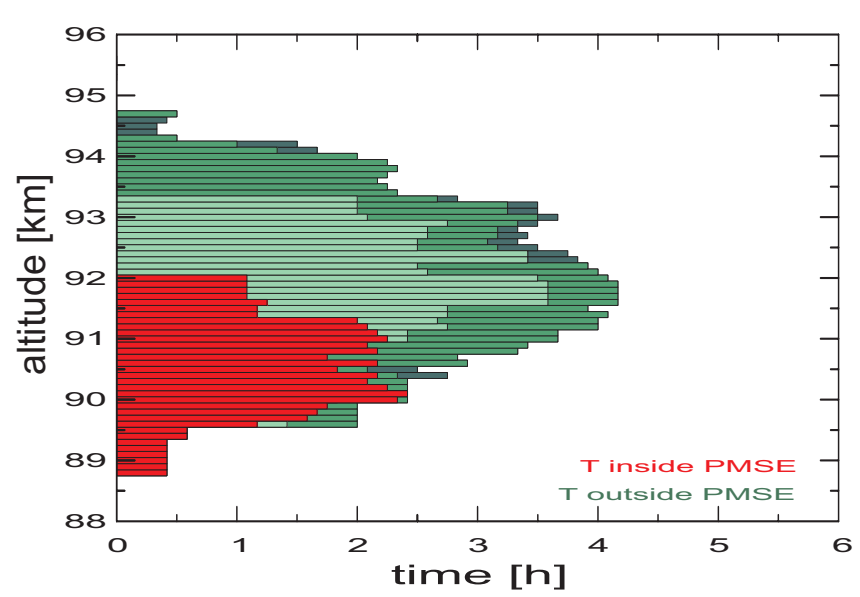

Fig. 4. Analysis of the time periods when supersaturation occurs. The dark green (red) bars shows the total time outside (inside) PMSE when the available time periods are sampled with a time slot of $15 \mathrm{~min}$. For the no-PMSE case we have repeated the procedure using a time slot of 30 (green) and 60 (light green) minutes.

constant is not known but an evaluation by Rapp and Thomas (2006), their Fig. 3, have shown that it can vary from minutes up several hours. In Fig. 4 we present a statistical analysis of the times when supersaturation occurs outside and inside PMSE. Based on a 5 min time grid with PMSE we count all cases where at least 3 successive grid points with temperatures less than $T_{f}$ occur. We repeat this procedure for the nonPMSE case and 3 (15 min), 6 (30 min), and 12 (60 min) successive grid points, respectively. For example, in the $15 \mathrm{~min}$ case we find at $\mathrm{z}=93 \mathrm{~km} 44$ grid points with $\mathrm{T}<\mathrm{T}_{\mathrm{f}}$, i.e. in total $44 \cdot 5=220 \mathrm{~min}(3: 40 \mathrm{~h})$. Using a time slot of $30 \mathrm{~min}$ we find 42 grid points resulting in a total of $210 \mathrm{~min}(3: 30 \mathrm{~h})$. Finally, the $60 \mathrm{~min}$ case gives $25 \cdot 5=125 \mathrm{~min}(2: 05 \mathrm{~h})$. Naturally, a finer sampling covers a larger part of the time series which explains why the $15 \mathrm{~min}$ analysis gives a larger total time compared to the $60 \mathrm{~min}$ interval. The results shown in Fig. 4 imply that supersaturation occurred for a period of some hours yet no PMSE was observed.

We expected that at least in some cases the ice particles would be lifted up due to transport processes, however throughout $5 \mathrm{~h}$ of measurement we never observe PMSE above $92 \mathrm{~km}$. In Fig. 5 we show the temperature deviations from the nightly mean temperature. Large temperature variations by up to $40 \mathrm{~K}$ and a downward progressing disturbance are present, presumably caused by a wave. The PMSE does not follow the downward progression of the wave front which indicates that the thermal and dynamical disturbance caused by the wave does not control the existence of PMSE.

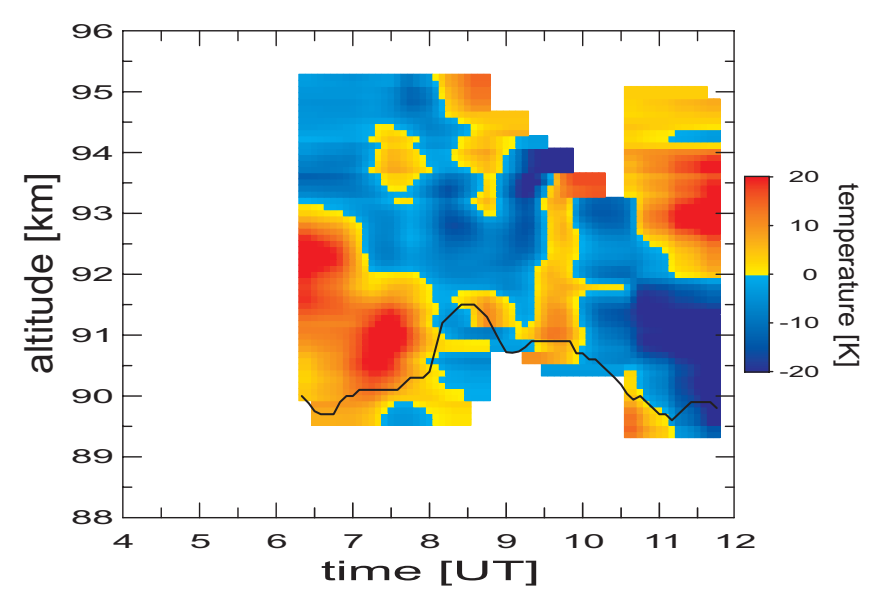

Fig. 5. Temperature deviations from the nightly mean temperature on 6 July 2003. The black line indicate the PMSE topside.

\section{Discussion}

We do not observe PMSE above $\sim 92 \mathrm{~km}$ altitude. This is in agreement with earlier measurements throughout the summer of 1999 and 2001 (Rüster et al., 2001; Lübken et al., 2004). The radar sensitivity of the SSR is comparable or even slightly larger than that of the ALWIN VHF radar (Latteck et al., 1999, 2005). The latter has been absolutely calibrated by Latteck et al. (2005) who also showed that ALWIN possess sufficient sensitivity to observe PMSE. Having in mind that the SSR is even slightly more sensitive this implies that the observed lack of PMSE at Spitzbergen is not a mere consequence of insufficient radar sensitivity.

Our temperature measurements show that it is persistently cold enough for ice particles but no PMSE are observed. The difference between actual measured temperatures and frost point temperatures (more than $20 \mathrm{~K}$ ) is much larger than typical uncertainties of the potassium lidar data (few Kelvin). The presence of ice particles does not disturb the temperature retrieval since it causes a frequency independent signal enhancement only, whereas temperatures are derived from the signal variation when the laser frequency is tuned over the potassium resonance line (Höffner et al., 2003). As has been shown by Höffner et al. (2006) potassium lidar temperatures nicely agree with falling sphere measurements (performed at the same place) considering uncertainties and instrumental limitations (e.g. altitude resolution) of both techniques. In addition, maximum temperatures inside the PMSE layer at lower altitudes $(\sim 91 \mathrm{~km})$ are close to the frost point temperature, as expected from the standard scenario of (charged) ice particles producing PMSE. In summary there are several independent indications that our potassium lidar temperatures are correct and that the uncertainties derived from our error analysis are realistic. 
According to the model of von Zahn and Berger (2003), the water-vapor mixing ratio at $94 \mathrm{~km}$ is approximately 0.5 ppmv. In the case of freeze-drying it is reduced by one order of magnitude. However, a reduction by a factor of $\sim 10000$ is required to reduce the frost point temperatures by $20 \mathrm{~K}$, which is unrealistic. Furthermore, ice particle modeling in the summer mesopause region has recently been improved and now includes natural variability of winds and temperatures (Berger and Lübken, 2006). Vertical winds redistribute water-vapor thereby reducing the effect of freeze-drying. In summary, we do not consider it likely that the water-vapor concentration was so extremely low during our measurements that this explains the non-existence of ice particles above $92 \mathrm{~km}$. The time constant for nucleation of these ice particles is so far not known. It can vary between minutes and several hours as discussed in Rapp and Thomas (2006). But it is expected that the ice particles are shifted in altitude by transport processes such as waves or winds. Surprisingly PMSE were never shifted higher than $92 \mathrm{~km}$ throughout our measurement which was lasting $5 \mathrm{~h}$.

\section{Summary and conclusions}

In our case study we have demonstrated that the lack of PMSE must not be interpreted as the temperature being too high for the existence of ice particles. Model results indicate that it is highly unlikely that the lack of PMSE is due to low water-vapor concentration. Obviously other geophysical parameters and processes are limiting the height range of PMSE and play an important role above $92 \mathrm{~km}$.

We have shown the first continuous time series of colocated and simultaneous measured temperature and PMSE at $78^{\circ} \mathrm{N}$. In the near future we will systematically compare all available potassium lidar temperatures and PMSE from Spitsbergen. Thereby we will get a more precise picture and the database to perform model calculations of PMSE to investigate the potential role of other geophysical processes affecting PMSE (e.g. turbulence, ionization, etc.).

Acknowledgements. The SOUSY Svalbard Radar data were collected in close cooperation with J. Röttger of the Max-PlanckInstitut für Aeronomie in Katlenburg-Lindau. We thank J.-S. Chen and J. Trautner for their assistance in operating the radar. We gratefully acknowledge the excellent support of the Svalsat team during installation and maintenance of the lidar. We thank C. FrickeBegemann, P. Keller, P. Menzel, T. Köpnick and J. Liu for their assistance with lidar operation. We also thank M. Rapp for helpful discussions on this topic. This research was supported by the German Space Agency (DLR) under grant 50 OE 9901 (ROMA).

Topical Editor U.-P. Hoppe thanks B. Williams and another referee for their help in evaluating this paper.

\section{References}

Berger, U. and Lübken, F.-J.: Weather in mesospheric ice layers, Geophys. Res. Lett., 33, L04806, doi:10.1029/2005GL024841, 2006.

Berger, U. and von Zahn, U.: Icy particles in the summer mesopause region: Three-dimensional modeling of their environment and two-dimensional modeling of their transport, J. Geophys. Res., 107(A11), 1366, doi:10.1029/2001JA000316, 2002.

Cho, J. Y. N. and Kelley, M. C.: Polar mesosphere summer radar echoes: Observations and current theories, Rev. Geophys., 31, 243-265, 1993.

Cho, J. Y. N. and Röttger, J.: An updated review of polar mesosphere summer echoes: Observation, theory, and their relationship to noctilucent clouds and subvisible aerosols, J. Geophys. Res., 102, 2001-2020, 1997.

Czechowsky, P., Rüster, R., and Schmidt, G.: Variations of mesospheric structures in different seasons, Geophys. Res. Lett., 6, 459-462, 1979.

Czechowsky, P., Klostermyer, J., Röttger, J., Rüster, R., and Schmidt, G.: The SOUSY-Svalbard-Radar for middle and lower atmosphere research in the polar region, in: Proceedings of the 8. Workshop on Technical and Scientific Aspects of MST Radar, edited by: Edwards, B., pp. 318-321, SCOSTEP, Boulder, Colorado, 1998.

Ecklund, W. L. and Balsley, B. B.: Long-term observations of the arctic mesosphere with the MST radar at Poker Flat, Alaska, J. Geophys. Res., 86, 7775-7780, 1981.

Fricke-Begemann, C., Alpers, M., and Höffner, J.: Daylight rejection with a new receiver for potassium resonance temperature lidars, Opt. Lett., 27(21), 1932-1934, 2002.

Goldberg, R. A., Fritts, D. C., Williams, B. P., She, C.-Y., Lübken, F.-J., Rapp, M., Singer, W., Latteck, R., Hoffmann, P., Müllemann, A., Baumgarten, G., Schmidlin, F. J., She, C.-Y., and Krueger, D. A.: The MaCWAVE/MIDAS rocket and groundbased measurements of polar summer dynamics: Overview and mean state structure, Geophys. Res. Lett., 31, L24S02, doi: 10.1029/2004GL019411, 2004.

Höffner, J. and Fricke-Begemann, C.: Accurate lidar temperatures with narrowband filters, Opt. Lett., 30, 890-892, 2005.

Höffner, J., Fricke-Begemann, C., and Lübken, F.-J.: First observations of noctilucent clouds by lidar at Svalbard, $78^{\circ} \mathrm{N}$, Atmos. Chem. Phys., 3, 1101-1111, 2003, http://www.atmos-chem-phys.net/3/1101/2003/.

Höffner, J., Lautenbach, J., Fricke-Begemann, C., and Lübken, F.-J.: Polar mesosphere temperature observations by lidar and falling sphere at $78^{\circ} \mathrm{N}$, in: Reviewed and Revised Papers Presented at the $23^{r d}$ ILRC Conference, Nara, Japan, 24-28 July 2006, edited by: Nagasawa, C. and Sugimoto, N., vol. ISBN49902916-0-3, pp. 373-376, 2006

Latteck, R., Singer, W., and Bardey, H.: The ALWIN MST radar Technical design and performances, in: Proceedings of the 14th ESA Symposium on European Rocket and Balloon Programmes and Related Research, edited by: Kaldeich-Schürmann, B., vol. ESA SP-437, pp. 179-184, Potsdam, Germany, 1999.

Latteck, R., Singer, W., Kirkwood, S., Jönssen, L., and Eriksson, H.: The ALWIN MST radar - Technical design and performances, in: Proceedings of the 17th ESA Symposium on European Rocket and Balloon Programmes and Related Research, edited by: Warmbein, B., vol. ESA SP-590, pp. 121-126, Sande- 
fjord, Norway, 2005.

Lübken, F.-J. and Müllemann, A.: First in-situ temperature measurements in the summer mesosphere at very high latitudes $\left(78^{\circ} \mathrm{N}\right)$, J. Geophys. Res., 108(D8), 8448, doi:10.1029/2002JD002414, 2003.

Lübken, F.-J., Rapp, M., and Hoffmann, P.: Neutral air turbulence and temperatures in the vicinity of polar mesosphere summer echoes, J. Geophys. Res., 107(D15), 4273, doi:10.1029/2001JD000915, 2002.

Lübken, F.-J., Zecha, M., Höffner, J., and Röttger, J.: Temperatures, polar mesosphere summer echoes, and noctilucent clouds over Spitsbergen (78 N), J. Geophys. Res., 109, D11203, doi: 10.1029/2003JD004247, 2004.

Marti, J. and Mauersberger, K.: A survey and new measurements of ice vapor pressure at temperatures between 170 and $250 \mathrm{~K}$, Geophys. Res. Lett., 20, 363-366, 1993.

Rapp, M. and Lübken, F.-J.: Polar mesosphere summer echoes (PMSE): Review of observations and current understanding, Atmos. Chem. Phys., 4, 2601-2633, 2004, http://www.atmos-chem-phys.net/4/2601/2004/.

Rapp, M. and Thomas, G. E.: Modeling the microphysics of mesospheric ice particles - Assessment of current capabilities and basic sensitivities, J. Atmos. Solar Terr. Phys., 68, 715-744, 2006.

Röttger, J.: Observations of the polar D-region and the mesosphere with the EISCAT Svalbard Radar and the SOUSY Svalbard Radar, Mem. Nat. Inst. Pol. Res., 54, 9-20, 2001.
Röttger, J., Schmidt, G., Rüster, R., Czechowsky, P., Klostermyer, J., Trautner, J., Meyer, K., Preschel, K. D., and Becker, H.: An update on he SOUSY-Svalbard-Radar: Observation of Polar Mesosphere Summer Echoes, in: Proceedings of the 9. Workshop on Technical and Scientific Aspects of MST Radar, pp. 427-430, Toulouse/France, 2000.

Rüster, R., Röttger, J., Schmidt, G., Czechowsky, P., and Klostermeyer, J.: Observations of Mesospheric Summer Echos at VHF in the Polar Cap Region, Geophys. Res. Lett., 28, 1471-1474, 2001.

She, C. Y., Williams, B. P., Hoffmann, P., Latteck, R., Baumgarten, G., Vance, J. D., Fiedler, J., Acott, P., Fritts, D. C., and Lübken, F.-J.: Simultaneous observation of sodium atoms, NLC and PMSE in the summer mesopause region above ALOMAR, Norway $\left(69^{\circ} \mathrm{N}, 12^{\circ} \mathrm{E}\right)$, J. Atmos. Solar Terr. Phys., 68, 93-101, doi:10.1016/j.jastp.2005.08.014, 2006.

von Zahn, U. and Berger, U.: Persistent ice cloud in the midsummer upper mesosphere at high latitudes: Three-dimensional modeling and cloud interactions with ambient water vapor, J. Geophys. Res., 108(D8), 8451, doi:10.1029/2002JD002409, 2003.

von Zahn, U. and Höffner, J.: Mesopause temperature profiling by potassium lidar, Geophys. Res. Lett., 23, 141-144, 1996. 